RESEARCH PAPER

\title{
Pak-US Economic Relations: Impacts on Pakistan's Economy
}

\author{
1Dr. Zahid Yaseen* ${ }^{2}$ Fajar Maqsood ${ }^{3}$ Dr. Muhammad Muzaffar
}

1. Assistant Professor, Department of Political Science GC Women University Sialkot, Sialkot, Punjab, Pakistan

2. MS Scholar, Department of Political Science GC Women University Sialkot, Sialkot, Punjab, Pakistan

3. Assistant Professor, Department of Political Science GC Women University Sialkot, Sialkot, Punjab, Pakistan

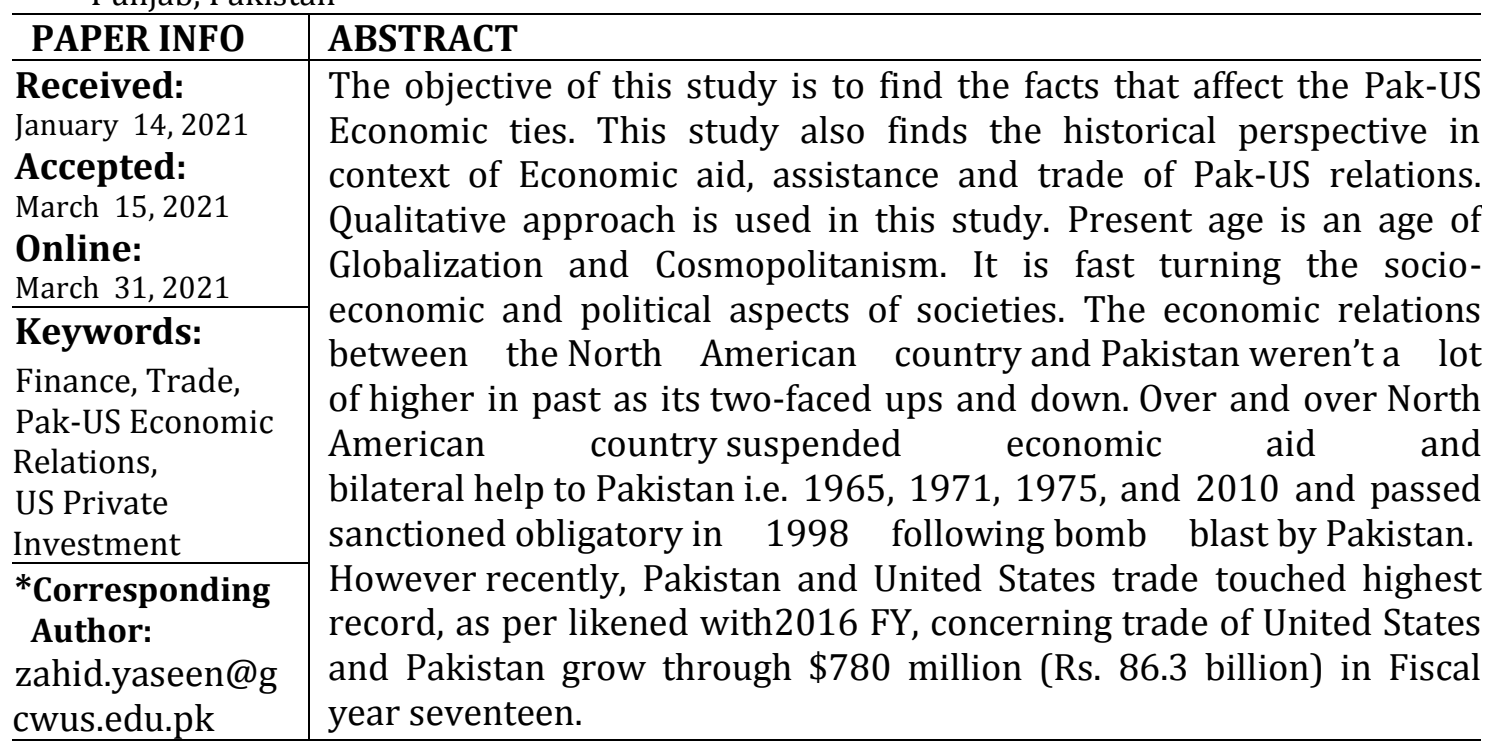

Introduction

It is palpable that economic relations between any two countries are overseen by the general discernment each has about the socio-economic and political setting of the country. It has been the US strategy in transit for creating nations when all is said in done and towards Pakistan in explicit, which has assumed incomparable significance. During virus war the world was bipolarized and the pioneers were attempting an ever increasing number of individuals for their group, so for this reason they gave them help and helped them, presently the time has changed before there were political contemplations however after the demise of virus war political contemplations have offered spot to the financial contemplations the states currently choose those strategies that give them monetary advantages now with the adjustment in universal governmental issues financial partnerships are shaped (Salim \& Kaleem, 2020).

United States of America remains one in every of the primary countries to possess established diplomatic ties with Islamic Republic of Pakistan. though the link dates back to Oct twenty, 1947, it often ciphers that the relations are primarily based strictly on military and economic support. During the underlying long stretches of Pakistan, the 
nation had the alternatives of structure loyalty with Soviet Union or United States; nonetheless, Pakistan decided on the last mentioned. Verifiably Pak-US relationship has never been reliable. It experienced many high points and low points in various periods. It was a result of assembly and dissimilarity of national interests that continued changing the two countries from kinship to rubbing (Hussain, 1987).

USA and Pakistan have been participating with one another in the monetary field as well as politically, socially and strategically. USA has constantly helped Pakistan in every one of these fields and has been one of the key partners in giving assets and backing.

Pakistan's vital fares to the US are outside provides, careful merchandise, cowhide and completed leather things, materials, cotton yarn, items of vesture, covers, and rice. Pakistan's basic imports from the U. S. are electrical equipment, gear, medications, dry natural product, fragrances, java and different sustenance things. The US has given uncommon concessions to People's Republic of Bangladesh on material fares, whereas the EU has had distinctive concurrences with Pakistan since 2013. Pakistan and also the US ought to consent to a discriminatory Trade Arrangement with the target of boosting their exchange to concerning $\$ 10$ billion (Rs. 1.1 trillion) throughout the subsequent 2 years. Each Pakistan and also the US should discover roads to enhance shared exchange what's to come back (Ahmar, 1984).

Pak-US relations can be investigated as deviated in light of the fact that since its beginning the pioneers of this recently conceived state went for financial and military help and needed to move toward becoming protectorate of US and up to this point Pakistan safeguard business as usual. In the event that one intensely investigates this rough plan among Pakistan and the United States, it tends to be finding out that as a result of Pakistan's asking frame of mind, the United States did not take a lot of torment in bringing Pakistan under her territory of impact. Be that as it may, an abrupt change in territorial situation with the nationalization of Iranian oil in 1951 reformed the strategy of extraordinary forces.

Efforts were created to bring up-gradation of transportation, mining, financial substructure etc. during this regard US proclaimed biological process aid of $\$ 1.6$ billion; $\$ 250$ million for the event of Baluchistan, $\$ 100$ million for the advance of coastal space of Makran, $\$ 70$ million were owed for long ventures e.g. water retrieval plant. In 1985, road connecting Bela to Turbat was erected from North American country aid program.

Likewise, in 1987, five hundred miles road connecting metropolis to Makran coast was erected from North American country funded program. Pakistan has gotten around US $\$ 70$ billion in United States outdoor guide as the situation initiation at the time of Pakistan's independence. It spots between highest beneficiaries of United States remote guide whole world over. Notwithstanding, it extravagant progression in U.S bucks towards Pakistan takes to great extent stood result of expanded Unites States key plus geo-political premiums trendy area plus' levels passing with year to year fluctuated aimed at a considerable length of time as US geopolitical premiums in the locale have moved. For example, 'in 1953 US offered financial and military help with coming back to Pak consent near connecting a coalition intended the spread to check socialism' (Kanwal, 2018). 
United States endeavors in Afghanistan to check Soviet expansionism saw extra curved expanded influx in United States outside help Government of Pakistan plus, best as of late, War on Terror of United States saw by Pakistan profiting significantly after United States remote help programs once more. Many contend that Pakistan keeps on outstanding vigorously subject to US outside guide, driving policymakers, lawmakers and advancement experts now West towards 'accept financial existence by Pak lays gifts as of US. Be that as it may, Pakistan's reliance on US has to a great extent been on US military help than financial.

\section{Literature Review}

The short examination of over a significant time span Pakistan-U.S financial ties, the creator speaks to a poor Third World country and the examination; I assume has the ordinary onlooker's predisposition. Thusly, we will concentrate fundamentally on the monetary component of Pakistan-U.S relations in the course of the last thirty-five years, explicitly three or four financial issues from the point of view of a Pakistani. Monetary relations among Pakistan and United states have encountered a checker history. The centrality of the connection between the two nations is reflected in the way that in 198485, US represented 10.4 percent of Pakistani fares, 12.3 percent of its imports (Iqbal, 2017).

Financial relations among Pakistan and United States have not accomplished the potential proposed by advancement on different fronts. Before, the United States had been the biggest wellspring of financial help to Pakistan. In the 1950 s, over the $66 \%$ of monetary help of Pakistan was from US. There another way, as a portion of all out authority advancement help given by US (Zaman, 2017).

The subject of doesn't fit broad exchange for the basic reason that with regards to in general U.S outside exchange and Investment that with Pakistan is moderately little. It isn't the motivation behind this introduction to inspect the details of U.S interest in and exchange with Pakistan generously commentary references to source materials but instead to express some U.S discernments applicable to the subject (Zuckerman, 2017).

US is the most compelling force on the planet today thusly, U.S international strategy and its relations with different countries, particularly with Pakistan in the South and West Asia is a conspicuous subject of universal governmental issues. This investigation comprehends the idea of U.S association with Pakistan. This additionally empowers us to comprehend the interior and outer powers. Truly Pak-U.S relationship has never been predictable. The overwhelming observation in Pakistan has been US increased more during the seasons of combinations of intrigue (Haqqani, 2017).

\section{The Initial Years (1947-1952)}

After the production of the two masteries of the British raj in 1947, "Pakistan required monetary help for its framework improvement and modernization of its military it isn't known with respect to when the administration of Pakistan chose to request military guide from the United States; field Marshal Ayub khan was unquestionably their living along these lives in August 1951. As a US partner in the district, Pakistan could give a dependable balance to the US in the area against any Soviet expansionist endeavors in South Asia. 
"From the U.S point of view, US was increasingly involved in the post war reproduction in Western Europe and Japan, its regulation endeavors in South East Asia and the Middle East. US in the underlying year of Pakistan was less keen on getting engaged with the developing clashes of South Asia".

\section{The Developing Economic Era of Ayub khan (1952-1969)}

US see as imperative to the national intrigue and world harmony the conservation of the autonomies and respectability on the countries of the Middle East. To this end, if the President decides the need thereof, US is set up to utilize military to help any such country or gathering of countries mentioning help against equipped hostility from any nation constrained by International Communism.

"if there should be an occurrence of hostility against Pakistan, the Government of the USA as per the circumstance of the USA will make such fitting move, including the utilization of military, as might be commonly settled upon and as is visualized in the Joint Resolution to advance harmony and strength in the Middle East, so as to help the Government of Pakistan at its solicitation". "The US observation flights over the Soviet Union from Peshawar Airport are a valid example" (Ali, 2009).

\section{The Initial Experience of 1965}

The 1965 Pakistan-India war was a rushed and a doomed issue on the vital plain by Pakistan. The ached status of a partner of U.S was put to rest for Pakistan. Those countries who don't finish the trial of fellowship should always be respected by the present and future age of Pakistanis as fakers and time servers for whom a country like Pakistan can have no utilization. We likewise should caution the dishonest in our middle since we know the there are some who are attempting to keep as under the spell of different fancies (Soherwordi, 2010).

\section{Pak US Relation regarding Aid}

In 1970s decision General Agha M. Yahya pioneer of Pakistani Party Awami association were come into control over Ayub Khan, the dynamic President yet the administration did not move their forces to the recently chose government and therefore the territory of Bangladesh was set up. The leaders of the Pakistan concentrating without anyone else benefits and needed a cozy association with the US government and for this reason they didn't offer consideration regarding the household issues (Chaudhry, 1987).

\section{Pak-US Economic Issues in Aid}

Until 1981, when "another relationship" was built up, Pakistan had been the 6th biggest beneficiary of U.S reciprocal financial help. The mass (around 40 percent) of this help (more than US $\$ 2$ billion) has been as far as nourishment help under US Public Law 480, around $33 \%$ was ware help, and somebody fifth was venture help (principally for farming and foundation).

Under the new bundles, the declining pattern in U.S, help to Pakistan has been turned around. The United States inspiration for the new bundle is in fact political: in the wake of the Iranian transformation and the Soviet attack of Afghanistan, it is currently the 
impression of the United States that "a solid and free Pakistan is in the common enthusiasm of the United States and Pakistan just as the whole world". The volume and terms of the financial help bundle have been planned, in this manner, to pad the equalization of installments effect of military deals at business terms (by and by, much equivalent to in 1981, around 14 percent for every annum). The two nations give off an impression of being happy with the dynamic improvement of the guide program (Salim \& Kaleem, 2020).

The new program is intended to accomplish four noteworthy commonly concurred financial destinations:

- Arrangement of considerable parity of installments supports for a period in which real guard and monetary speculations are to occur.

- Confirmation of stable and generally quick dispensing capital streams to encourage methodical arranging over a more extended time than expected for help programs.

- A promise to a concurred rundown of high-need ventures that would add to long haul, self-continuing financial development in Pakistan.

- Sectoral grouping of interests in two noteworthy zones: horticulture/water system and vitality.

The projects and tasks that have been created mirror these needs. Some $\$ 300$ million is modified for rural wares and hardware. Generally $50 \%$ of this entirety would fund imports of phosphate manures, not yet created in Pakistan and a sizable bit of overwhelming hardware to keep up water system channels. Some $\$ 300$ million is for the import of vegetable oil for the assembling of ghee. Another $\$ 90$ million would bolster upgrades in task and upkeep of Pakistan's huge water system foundation with an end goal to improve productivity and lessen repeating costs. More than $\$ 52$ million will fund current warmth recuperation gas turbine generators at the Guddu power plant, which would essentially improve the productivity of petroleum gas use in the power area. The United States is likewise expected to take part in financing, to the degree of \$125 million for 1986 and 1987, the proposed Lakhra coal-terminated electric age venture at Jamshoro in Sindh, the main huge scale abuse of Pakistan's significant lignite coal saves for power age (Khan \& Ahmed, 2007).

Nearly \$94 million has been dispensed to provincial advancement extends in the more detached and least created districts of Baluchistan and the North-west Frontier Province (NWFP). This would incorporate some $\$ 30$ million for country improvement and rural tasks in region that have generally delivered opium poppies under the NWFP region advancement. It would enable ranchers to make a monetary change in accordance with new harvests as they ordinarily with the administration's implementation of the national prohibition on poppy development.

Major concerns, in any case, may rise on each side. For Pakistan it is significant that the concurred program of dynamically expanding degrees of financial help. Second, Pakistan's requirement for joined together, speedy dispensing help perceived by the two gatherings should be kept in view, in U.S, two-sided help however in the U.S position in multilateral guide discussions, particularly the Aid-to-Pakistan Consortium. At long last, in perspective on the settled requirements for outside help with financing the high-need Sixth Five-Year plan (1982-88) ventures, valuable endeavors the net progression of remote help 
could be made. All the more fundamentally, be that as it may, net streams could be improved by U.S backing of an advancement way to deal with obligation advancement way to deal with obligation rebuilding as a quick method for expanding net exchanges instead of the conventional idea of obligation alleviation as a last endeavor to rescue lost advances. In addition, from an acquiring nation's perspective, one dollar of obligation help is worth considerably more than one dollar of tied guide (Epstein \& Kronstadt, 2011).

\section{Pak-U.S Trade}

The saying that exchange pursues the banner seems, by all accounts, to be reflected in the monetary connection among Pakistan and US. The recharged close political connection has concurred with a development in both exchange and in re-established U.S private speculation enthusiasm for Pakistan.

Over the previous decade the U.S-Pakistan exchange example has reliably appeared generous equalization for the United States, an example liable to continue. The respective exchange between the two nations was not broad in the mid-1970s but rather climbed considerably in the late 1970s, a pattern which quickened during the 1980s with the exception of a dunk in 1981. In 1982, U.S fares to Pakistan added up to $\$ 700$ million made fundamentally out of hardware and transport gear, creature and vegetable oils and fats, and mechanical apparatus and media transmission hardware. Pakistani fares to the United States that equivalent year totaled $\$ 181$ million, comprising for the most part of materials, wearing clothing, creatures and vegetable materials and shellfish.

The Commerce department in May 1984 outside Economic Trends report on Pakistan considers Pakistan to be putting forth an extending market for American merchandise and ventures. For example, wheat and urea manure, when huge U.S fares to Pakistan, have been essentially wiped out by expanded Pakistani generation of these merchandise.

\section{Pak-U.S Economic Issues in Trade}

Not at all like guide connection, exchange connection among Pakistan and the United States, reflecting overall patterns, have been assailed with more noteworthy troubles. It is here that the exchange arrangement of the United States, notwithstanding considering decision year madness's, must extension the developing hole among training and lecturing. In enormous part, there is a worldwide viewpoint to it, managed as a NorthSouth issue underneath, under which access to business sectors should at any rate be viewed as a basic.

Fixing in any approach of worldwide obligation the board, if more established contentions with the expectation of complimentary exchange appear to be less powerful. Be that as it may, even in respective relations, the United States needs to set a model for the remainder of the countries in OECD.

The imports of Pakistan from the United States reliably surpass its profit from fares to the United States and help receipts set up together. Also, Pakistan needs to meet its obligation administration commitment. This installments awkwardness, for the United States, which gathers as obligation, can be amended either by improved guide streams or by expanded to Americana Markets. The financial rationale couldn't be less difficult. 
However the equalization of Political bit of leeway inside the United States (and other loaning nations) reliably supports a case-by-case approach, which dodges the main problems (Sohrab \& Choudhry, 2012).

The fundamental issue is material exchange, Pakistan's primary fabricated fare, which is administered by the MFA. Under the Multi-fibre arrangements, Pakistan has consented to a Bilateral Textile Arrangement with the US, which controls Pakistan's fare of material items through "total cutoff points" on fares. There is no motivation behind why these total cutoff points can't be considerably upgraded, if not wiped out and out. What's more, the United States has depended on warning of one-sided restriction against imports of certain classifications of material items from Pakistan. Meetings between the two governments are in advancement to determine this issue. A progressively dynamic modification program, with a period bound timetable and screen capable targets, ought to be actualized, maybe under suspires of the World Bank or the IMF, in light of a legitimate concern for all gatherings.

The push toward a dynamic disposal of wasteful exchanging rehearses materials ought to be enhanced by more prominent advancement of special levy's given to poor nations through the Generalized Systems of Preferences (GSP). The U.S plan of GSP cover somewhere in the range of 2,900 items from 140 creating nations and regions. Regardless of fast development, the United States GSP imports added up to just $\$ 8.4$ billion of every 1981 or nearly 3 percent of all out imports (Hussain, 2016).

Pakistan's GSP fares to the United States have expanded to $\$ 40.5$ million out of 1982-83, or some 17.4 percent of Pakistan's all out fares. Regardless of whether recompenses are made for the absence of commonality of Pakistani exporters with a relatively new plan and for Pakistan's chief fare items lie outside the domain of the plan, the rate of usage of the plan has been low. Notwithstanding a general extension in the plan, the accompanying explicit measures could support Pakistan's fares:

1. The rundown of items could be extended to incorporate things important to Pakistan.

2. Issue coming about because of specialized highlights of the plan ought to be reviewed to discover approaches to advance GSP fares.

3. Usage of the plan can be expanded by U.S experts by giving specialized help to acquainting Pakistan's exporters with different perspectives and systems of the plan.

\section{U.S Private Investment in Pakistan}

The aggregate sum of direct U.S private interest in Pakistan before the 1983 OPIC venture mission had remained for all intents and purposes unaltered, at $\$ 109$ million, since 1979. The biggest speculation of capital had been in the oil investigation division and the biggest U.S assembling endeavors were two urea compost plants, the recently referenced Hercules joint endeavor with the Dawood gathering, and an Exxon plant. Out of the thenaggregate of twenty-three direct U.S interests in Pakistan's mechanical area; thirteen were pharmaceutical speculations.

U.S business working in Pakistan has been supported by the more ideal demeanor by the legislature toward business premiums by and large and toward outside interest specifically. Notwithstanding the issue sketched out above, there is in the occupant U.S business network in Pakistan proceeded with disappointment with over guideline, benefit 
hindering fixed rates of return, and general gradualness in completing thing and choice taken. A few of the built up U.S pharmaceutical firms have extended or plan to do as such while others is moving from bringing in items for neighborhood deal to assembling in Pakistan.

\section{Net Inflow of Capital since US}

FPl assets from US have shown a rising pattern as of late. In 1983-84 the inflow from the United States added up to Rs 150 million. This was 29.4 percent of the all-out net progression of Private capital in the year. A significant component of U.S PFI as of late is that the assets as reinvested profit have expanded.

In spite of Pakistan's endeavors to make a helpful domain by method for guaranteeing the wellbeing of remote capital and a bundle of impetus, U.S ventures have not enlisted any momentous increment. Undoubtedly, it is hard to break the global remote capital stream design where worldwide capital for PFI has separated zones of consideration. As indicated by this example three-fourths of private remote speculation goes to created nations and one-fourth for creating nations. Thusly, a lot of private remote venture at about Rs 9 billion is far not exactly just U.S speculations if $\$ 9.0$ billion in Brazil and $\$ 3$ billion in Argentina. Without a doubt, even among Asian nations U.S outside speculations have inclination for different nations. In this way, a straightforward motivator bundle and certification for capital assurance don't give off an impression of being adequate to draw in U.S funding to Pakistan (Shah, et. al. 2010).

Disregarding the restricted inflow of assets, in the previous couple of years Pakistan has endeavored to step toward drawing in U.S capital. Notwithstanding reassuring outside interest in enterprises that are capital-escalated, import substitution and fare situated and require refined innovation, the legislature has most as of late accentuated the requirement for joint endeavors in argic-ventures and light designing undertakings. Both people in general and private division are looking for has as of late procured value cooperation and specialized coordinated effort.

\section{US-Pakistan Trade Facts}

In 2018, Pakistan GDP was an estimated $\$ 312.6$ billion (current market exchange rates); real GDP was up by an estimated 5.2\%; and the population was 201 million. (Source: IMF)

Pakistan is currently our 56th largest goods trading partner with $\$ 6.6$ billion in total (two way) goods trade during 2018. Goods exports totaled $\$ 2.9$ billion; goods imports totaled $\$ 3.7$ billion. The U.S. goods trade deficit with Pakistan was $\$ 783$ million in 2018 .

According to the Department of Commerce, U.S. exports of goods to Pakistan supported an estimated 10 thousand jobs in 2015.

\section{Exports}

- Pakistan was the United States' 55th largest goods export market in 2018.

- U.S. goods exports to Pakistan in 2018 were $\$ 2.9$ billion, up 4.3\% (\$121 million) from 2017 and up 54.3\% from 2008. 
- The top export categories (2-digit HS) in 2018 were: miscellaneous grain, seeds, fruit (soybeans) ( $\$ 694$ million), cotton ( $\$ 615$ million), iron and steel (\$225 million), machinery ( $\$ 211$ million), and optical and medical instruments ( $\$ 117$ million).

- U.S. total exports of agricultural products to Pakistan totaled \$1.5 billion in 2018, our 19th largest agricultural export market. Leading domestic export categories include: soybeans ( $\$ 689$ million), cotton ( $\$ 615$ million), tree nuts ( $\$ 49$ million), dairy products (\$38 million), and planting seeds (\$37 million).

\section{Imports}

- $\quad$ Pakistan was US 58th largest supplier of goods imports in 2018.

- U.S. goods imports from Pakistan totaled $\$ 3.7$ billion in 2018, up 3.9\% (\$138 million) from 2017, and up 3.4\% from 2008.

- The top import categories (2-digit HS) in 2018 were: miscellaneous textile articles ( $\$ 1.3$ billion), knit apparel ( $\$ 809$ million), woven apparel ( $\$ 586$ million), leather products ( $\$ 121$ million), and cotton ( $\$ 112$ million).

- U.S. total imports of agricultural products from Pakistan totaled \$126 million in 2018. Leading categories include: rice ( $\$ 31$ million), sugars, sweeteners, bev bases ( $\$ 30$ million), spices ( $\$ 19$ million), processed fruit \& vegetables ( $\$ 9$ million), and snack foods ( $\$ 7$ million).

From 2001-02 onwards, after 9-11 and Pakistan's help to the US in the Afghan war, the underlying progression of help every year drew closer $\$ 2.0$ billion. During the Musharraf Government, all out help got was near $\$ 12$ billion. It topped during the residency of the PPP Government when $\$ 16$ billion were gotten in the five years. This was encouraged by the Kerry Lugar bill whereby the US Congress approved significantly increasing of financial help to Pakistan.

Be that as it may, since 2012-13, the degree of help has fallen forcefully. It is assessed at $\$ 5$ billion in the course of the most recent four years. In 2016-17, it declined to not exactly $\$ 800$ million, with CSF inflow of $\$ 650$ million. To make up for this, fares should expand more by just 4 percent. In this way, the procedure of retreat of the US from help to Pakistan had just been in progress for quite a while.

The significant message is that monetary and security help is the least fundamental piece of the financial relations among Pakistan and the US. The more significant connections are in exchange and the inflow of settlements. The US is the biggest fare market of Pakistan, with a volume of $\$ 3.7$ billion of every 2016-17. This speaks to 17 percent of the complete fares of Pakistan. Further, the US is one of only a handful couple of nations with which Pakistan has an exchange overflow, drawing nearer $\$ 1.6$ billion of every 2016-17.

The flow of remittances is also sizeable from the US. Last year it was $\$ 2.5$ billion, equivalent to 13 percent of total remittances. As from many other countries, there has been a significant decline since 2014-15.

The other territory where the association with the US has debilitated is in the inflow of outside direct and portfolio speculation to Pakistan. In 2014-15, outside private venture from the US to Pakistan was generally high at $\$ 823$ million, significantly higher 
than that from China. From that point, China has overwhelmed the US. During the most recent two years, the inflow from China is $\$ 2.3$ billion when contrasted with $\$ 600$ million from the US. This distinction is probably going to be amplified with cresting of CPEC ventures.

The discontinuance of US help ought to not materially affect Pakistan's economy as the level had effectively fallen significantly. Different elements of the relationship, particularly exchange and settlements, are probably going to remain to a great extent unaffected. Ideally, Pakistani ostracize laborers in the US may send more to Pakistan to show their help right now.

The Government and the Military have taken the proper position as for the US. The interest to 'accomplish more' is obviously inadmissible. Pakistan has effectively paid an overwhelming cost meant for battle taking place fear.

The direst outcome imaginable is the thing that could occur if Pakistan is left with no choice yet to approach the IMF for a Program. In 1998, when authorizations were set by the US on Pakistan, beginning contact with the Fund was met by, pretty much, incomprehensible earlier activities being requested. These incorporated a precarious cheapening, enormous climb in assessment rates and power levies, etc.

The opportunity has arrived now to move unequivocally towards more noteworthy confidence rather than just a 'holding activity' with least approach activity till the following races. It is basic that an a lot more grounded exchange approach be set up on a need premise. The forms of such an approach have just been depicted article by the writer in 'A Stronger Trade Policy' conveyed by this paper as of late.

\section{Conclusion}

The opportunity has arrived now to move unequivocally towards more noteworthy independence rather than just a 'holding activity' with least approach activity till the following races. It is basic that an a lot more grounded exchange approach be set up on a need premise. The forms of such an arrangement have just been depicted article by the writer in 'A Stronger Trade Policy' conveyed by this is as of late.

There is need for evolving a political consensus on the steps to improve the external balance of payments position and averting a financial crisis. This will be a clear demonstration that Pakistan is now a mature and a sovereign nation.

Pakistan's money related resistances are defenseless. The country needs to meet up to actualize the politically troublesome yet indispensable expense and different estimates required to guarantee a supported parity in the nation's financial and outside records. For the more extended period, endeavors of China should be joined by Pakistan, Russia plus nearly different nations towards develop exchange or else beneficial plans toward United States-overwhelmed budgetary framework.

\section{Recommendation}

Thus, despite the fact that United States authorized help toward Pak shall negligible and contingent, Pak must attempt to welcome US private venture into the 
immense and undiscovered financial open doors which occur in pretty much each part Pakistan's frugality. Aside from fund, such venture will bring propelled the board systems and generation advances Pakistan.

Pakistan's restored association with Saudi Arabia and the UAE offers another road for backhanded financial Pakistan-US participation. Essentially, Saudi and UAE interests in the vitality and petrochemicals divisions, other than possibly fabricating Pakistan's extensions with US corporate, will likewise interface them, by means of oil and gas trades, to China and Central Asia through Pakistan. 


\section{References}

Ahmar, M. (1984). Pakistan-United States Relations. Berkeley, California

Ali, M. (2009). US aid to Pakistan and democracy. Policy Perspectives, 119-132.

Chaudhry, G. M. (1987). The Dynamics of Images: US-Pakistan Relationship. Pakistan Journal of American Studies, 5(1), 18.

Epstein, S. B., \& Kronstadt, K. A. (2011). Pakistan: US foreign assistance. Washington, DC: Congressional Research Service.

Foreign Affairs, Defense, and Trade Division. (2003, February). India and Pakistan: US Economic Sanctions. Congressional Research Service, Library of Congress.

Hanif, M. (2013). Pakistan-Russia relations: Progress, prospects and constraints. IPRI Journal, 13(2), 63-86.

Haqqani, H. (2017). Iranian, Chinese, and Indian Policies on the Afghan War. Pak US Relations, 75-82.

Hussain, S. R. (1987). Pak-Soviet Relations since 1947: A Dissenting Appraisal. Strategic Studies, 10(3), 64-88.

Iqbal, Z. (2017). Pakistan-U.S. Economic Relations: Trade and Foreign Investment. PakistanU.S. Relations, 269-279.

Kanwal, G. (2018). Pakistan's Gwadar Port. Center for Strategic and International Studies.

Khan, M. A. (2011). Foreign direct investment in Pakistan: The role of international political relations. University of Oxford, Department of International Development.

Khan, M. A., \& Ahmed, A. (2007). Foreign aid-blessing or curse: Evidence from Pakistan. The Pakistan Development Review, 215-240.

Kumar, S. (2007). The China- Pakistan strategic relationship: Trade, investment, energy and infrastructure. Strategic Analysis, 31(5), 757-790.

Raza, Syed \& Sarwar Sabir, Muhammad \& Mehboob, Farhan. (2011). Capital inflows and Economic growth in Pakistan, MPRA Paper No. 36790

Salim, A., Ullah, W., \& Kaleem, M. (2020). Pak-US Strategic Partnership and Controversial Issue of Aid after 9/11. Dialogue, 15(1), 1-10.

Shah, H, Hasnat, S. H., \& Li, J. (2010). Does foreign capital inflows really stimulate domestic investment: a case study of Pakistan. MPRA Paper

Soherwordi, S. H. S. (2010). US Foreign Policy Shift towards Pakistan between 1965 \& 1971 Pak-India Wars. South Asian Studies, 25(1),21-37

Sohrab, W., \& Choudhry, I. (2012). Pak-US Relations in 21st Century: Challenges and Opportunities for Pakistan. Berkeley Journal of Social Sciences, 2(3), 1-16. 
Zaman, A. (2017). The New Multiyear Aid Program: The Pakistani View. Pakistan-U.S. Relations, 252-258.

Zuckerman, M. (2017). U.S.-Pakistan Economic Relations: Trade, Foreign Investment, and Technology Transfer Issues. US Pakistan Relations, 280-292. 